Dicle Tıp Dergisi / Dicle Med J (2018) 45 (3) : 245-253

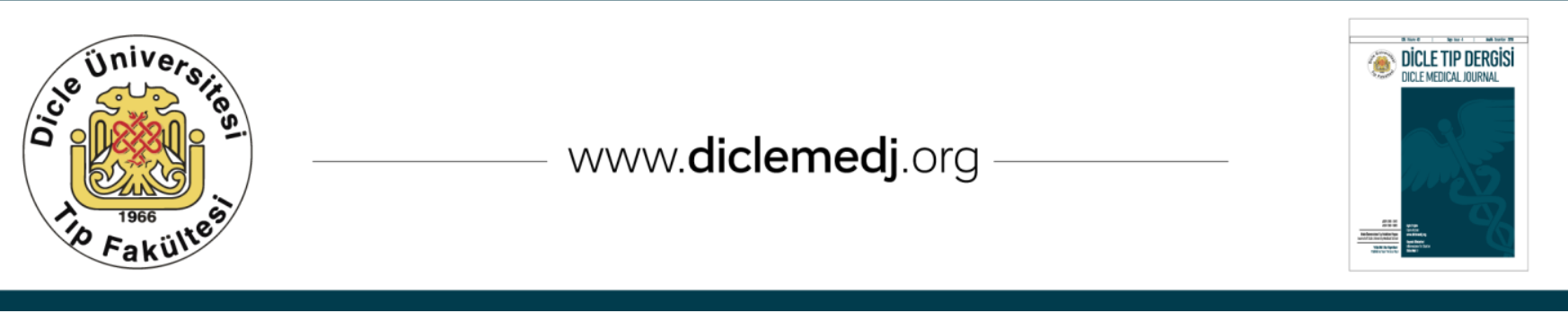

Original Article / Özgün Araştırma

\title{
Stereotactic biopsy of the brain mass lesions: a tertiary hospital experience
}

\author{
Erkut Baha Bulduk¹, Ayfer Aslan², Özgür Öcal ${ }^{3}$, Ömer Hakan Emmez, \\ Gökhan Kurt' ${ }^{5}$, Şükrü Aykol'
}

1 Eskisehir Government Hospital, Department of Neurosurgery, Eskisehir, Turkey ORCID: 0000-0002-8812-1290 2 Sirnak Government Hospital, Department of Neurosurgery, Sirnak, Turkey ORCID: 0000-0002-5413-7833

3 Department of Neurosurgery, Yıldırım Beyazıt University Hospital, Ankara, Turkey ORCID: 0000-0002-8985-2626

4 Gazi University, Faculty of Medicine, Department of Neurosurgery, Ankara, Turkey ORCID: 0000-0002-3290-179X

5 Gazi University, Faculty of Medicine, Department of Neurosurgery, Ankara, Turkey ORCID: 0000-0002-2773-056X

6 Gazi University, Faculty of Medicine, Department of Neurosurgery, Ankara, Turkey ORCID: 0000-0001-7896-1563

Received: 09.12.2017; Revised: 11.06.2018; Accepted: 13.07.2018

\begin{abstract}
Objectives: Stereotactic biopsy (SB) is a guided technic performed for the lesions on eloquent brain areas. The aim of this study is revealing the diagnostic reliability and the risk ratio of SB.

Methods: Data of patients performed SB due to various intracranial lesions was collected retrospectively. The study took place in Department of Neurosurgery, Gazi University Faculty of Medicine between February 2004 and April 2014. Data analysis performed in terms of age, gender, lesion location, histopathology, and outcomes of surgery.

Results: Sixty percent of patients were male (146 patients) and forty percent of them was female (96 patients), between the ages of 11 and 84 years (mean age of 49 years) with a total number of 242 . Mortality and morbidity rates were respectively $0.4 \%$ and $3.3 \%$. The overall diagnostic yield was $81 \%$ (196 patients), while 19\% (46 patients) had nonspecific results, which did cannot lead any further therapy. Among 36 patients of whom pathologies were confirmed with an excisional biopsy, the diagnostic accuracy was shown in 24 patients (67\%).

Conclusions: Beside low risk of mortality and morbidity, the high rate of non-diagnostic results and low rate of diagnostic accuracy are the limitations of SB, which should be improved by careful skills to obtain more specimen, sophisticated software for planning, and intraoperative pathological examination for guaranteeing.
\end{abstract}

Keywords: Stereotactic biopsy, Brain tumor, Neurosurgery

DOI: $10.5798 /$ dicletip. 457233

Yazışma Adresi / Correspondence: Erkut Baha Bulduk, Eskisehir Government Hospital, Department of Neurosurgery, Eskisehir, Turkey e-mail: erkutbahabulduk@hotmail.com 


\section{Beyin kitle lezyonlarının stereotaktik biyopsisi: Üçüncü basamak hastane deneyimi}

\section{Öz}

Giriş: Stereotaktik biyopsi , hassas beyin bölgelerindeki lezyonlar için uygulanan bir tekniktir.

Amaç: Bu çalışmanın amacı stereotaktik biyopsinin tanısal güvenilirliğini ve risk oranını ortaya koymaktır.

Yöntemler: Çeşitli intrakranyal lezyonlar nedeniyle stereotaktik biyopsi uygulanan hastaların verileri geriye dönük olarak toplanmıştır. Çalışma, Şubat 2004 ile Nisan 2014 tarihleri arasında Gazi Üniversitesi Tıp Fakültesi Nöroşirürji Anabilim Dalı'nda gerçekleștirilmiştir. Veri analizi; yaş, cinsiyet, lezyon yeri, histopatoloji ve cerrahi operasyon sonuçlarına göre yapılmıştır.

Bulgular: Hasta sayısı; yaşları 11 ile 84 arasında (ortalama yaş 49), yüzde altmışı erkek (146 hasta) ve yüzde kırkı kadın (96 hasta) olmak üzere toplam 242 idi. Mortalite ve morbidite oranları sırasıyla \%0,4 ve \%3,3'tür.

Tanı koyma oranı \%81 (196 hasta) iken, \%19'unda (46 hasta) tedavi modalitesini ilerletemeyeceğimiz nonspesifik sonuçlar vardı.

Patolojileri eksizyonel biyopsi ile onaylanan 36 hasta arasında tanısal doğruluk 24 hastada görüldü (\%67).

Sonuç: Düşük mortalite ve morbidite riski yanında, tanısal olmayan sonuçların yüksek ve tanısal doğruluğun düşük oranı stereotaktik biyopsinin sınırlamalarıdır. Daha fazla numune almak için dikkatli beceri, planlama için gelişmiş yazılım kullanımı ve intraoperatif patolojik inceleme ile tanısal doğruluk oranı arttırılabilinir.

Anahtar Kelimeler: Stereotaktik biyopsi, beyin cerrahisi, beyin tümörü.

\section{INTRODUCTION}

Horsley and Clarke first reported stereotactic surgery in $1908^{1}$, with a new device enabling the precise positioning of probes into targeted structures of a monkey brain. Then, Spiegel and Wycis started human stereotactic surgery with injecting alcohol stereotactically into the globus pallidus and dorsomedial thalamic nucleus of a patient for treatment of Huntington's chorea in $1946^{2}$. With the innovation of computed tomography, this method has been developed and used commonly. Hall at al. reported almost 7500 stereotactic cases in their study published in 19983. This technic has been applied in our clinic since 2004, and we currently use the magnetic resonance imaging (MRI) - guided stereotaxic technics.

One of stereotactic surgery technics is stereotactic biopsy (SB), which is indicated for patients with high risks for general anesthesia like overage or comorbidities, unresectable lesions as diffuse infiltrative (encephalitis, vasculitis or lymphoma etc.), multifocal or on eloquent brain areas. SB is a favorable opportunity owing to high accuracy and low mortality and morbidity for patients with symptomatic brain lesions on eloquent areas that show diagnostic challenges could not be ruled out with other diagnostic tests such as radiological evaluation ${ }^{4-6}$.

The general principle in neurosurgery is the removal of the tumor as much as possible; this does not always mean the better outcome. Whenever the excisional surgery will not result in favorable outcomes for the patient, a minimally invasive technic as SB should be preferred if a histopathological diagnosis is required. On the other hand, the safety and efficacy of the surgical technic are important as much as patient selection. SB had been previously reported as an extremely safe and effective procedure with high diagnostic yield, and low mortality, and morbidity rate for evaluating intracranial lesions ${ }^{10}$. Regarding the differences between clinics, we aim to explore the diagnostic accuracy and risk rates of SBs belonging to our clinic. 


\section{METHODS}

The data of patients who had been operated due to various intracranial lesions with stereotactic biopsy in Department of Neurosurgery, Gazi University Faculty of Medicine between February 2004 and April 2014 was collected retrospectively. The data was analyzed based on age, gender, lesion localization, histologic type of the lesions, and clinical outcomes as mortality and morbidity.

All included patients were taken to GammaKnife unit after preoperative intravenous antibiotic administration. Following placement of the Leksell stereotactic frame (Elekta, Stockholm, Sweden), planning was done with MR navigation for guidance (Figure 1). Then the patients were taken to the operating room. Following the appropriate cleaning and covering of surgery site, local anesthesia was applied to the incision line determined according to the coordinates. Linear skin incision was made with scalpe followed by hemostasis with monopolar and bipolar electrocautery. The skin flap was rolled and a burr hole was formed with an electric drill, and the dural adhesions were removed through the burr hole with the Penfield dissector. The dura was opened as " + " according to the coordinates and mass lesion was reached within parenchyma. Multiple biopsies were taken from $+1,0$ and $-1 \mathrm{~cm}$. Subcutaneous layer was sutured with $2 / 0$ vickryl, skin was sutured with stapler.

SBs were performed under local anesthesia and conscious sedation. A trajectory bypassing major vasculature, sulci and cerebrospinal fluid spaces were chosen in each patient according to the location of the lesion and multiple biopsies were taken along the planned trajectory between $1 \mathrm{~cm}$ proximal and $1 \mathrm{~cm}$ distal to the center of the aimed lesion.

A postoperative cranial computed tomography (CT) scan was performed routinely in every patient within 24 hours to rule out any complications and for confirmation of accuracy of the route.

The patients were grouped according to lateralization of the lesions in the brain as the middle, right side and left side; according to the location of the lesions as frontal, parietal, temporal, occipital, thalamus, third ventricle and infratentorial (pons, and cerebellum). The histopathologic results of the specimens were determined in 9 groups as nonspecific group consisted of glial cells or gliosis; low-grade glial tumors (grade 1 and 2 astrocytomas, oligodendrogliomas, $\quad$ grade 2 oligoastrocytomas, chondroid gliomas); high grade glial tumors (grade 3 astrocytoma, anaplastic oligoastrocytoma, glioblastoma multiforme, gliosarcoma); lymphomas; metastases (adenocarcinoma, squamous cell carcinoma, endometrial tumor, malign mesenchymal tumor, malign epithelial tumor, ring cell carcinoma, gastrointestinal stromal tumor metastases); infectious processes (bacterial and viral inflammatory changes, tuberculoid granulomatous inflammation, encephalitis, outside substance, and abscesses); radiation necrosis; hematoma and the others (primitive neuroectodermal tumor, neurocytoma, ependymoma, germinoma, choroid plexus papilloma, cavernous hemangioma, hemangioblastoma).

The complications of SBs were analyzed according to radiological and clinical examinations. Radiological examinations were performed by computed tomography (CT) after SB within 24 hours, while clinical outcomes were detected according to morbidity and mortality results. The morbidity caused by SB was considered in the case of new neurological deficits or worsening in the existing deficits. Mortality associated to the SB was determined as death within 30 days after the procedure. The deaths happened after that time were related to the existing tumor, and unrelated to SB. 


\section{RESULTS}

There were 242 patients of whom $60 \%$ (146 patients) was male and $40 \%$ (96 patients) was female in a range of age between 11 and 84 years (mean age of 49 years). Lesions were in the midline in $12 \%$ (28 patients), in the right hemisphere in $42 \%$ (103 patients) and in the left hemisphere in 46\% (111 patients). The lesions were in the frontal lobe in 32\% (78 patients), in the parietal lobe in 23\% (55 patients), in the temporal lobe in $17 \%$ (41 patients), in the occipital lobe in 5\% (13 patients), in the thalamus in 19\% (45 patients), in the third ventricle in 3\% (8 patients), and infratentorial in $1 \%$ ( 2 patients) (Table I).

Table I: Characteristics of 242 patients who underwent stereotactic biopsy between 2004 and 2014

\begin{tabular}{|ll|}
\hline No. of patients & 242 \\
Mex (M/F) & $146(60 \%) / 96(40 \%)$ \\
Tumor location & 49 (range, 11-84) \\
Left & $111(46 \%)$ \\
Right & $103(42 \%)$ \\
Middle & $28(12 \%)$ \\
Frontal & $78(32 \%)$ \\
Parietal & $55(23 \%)$ \\
Thalamus & $45(19 \%)$ \\
Temporal & $41(17 \%)$ \\
Occipital & $13(5 \%)$ \\
Third ventricle & $8(3 \%)$ \\
Infratentorial & $2(1 \%$, one cerebellum, one pons) \\
\hline
\end{tabular}

The histopathology of the lesions resulted as nonspecific which did not lead any further therapy (glial cells or gliosis, insufficient material) in 19\% (46 patients), besides a specific diagnosis was determined in 81\% (196 patients). High-grade glial tumor (grade 3 astrocytoma, anaplastic oligoastrocytoma, glioblastoma multiform) resulted in 31\% (75 patients); low-grade glial tumor (grade 1 and 2 astrocytomas, oligodendrogliomas, grade 2 oligoastrocytomas, chondroid glioma) in 18\% (43 patients); infectious processes (bacterial and viral inflammatory changes, tuberculoid granulomatous inflammation, encephalitis, outside substance, and abscesses) in $10 \%$ (25 patients), lymphoma in $8 \%$ (20 patients); metastasis (adenocarcinoma, squamous cell carcinoma, malign mesenchymal tumor, malign epithelial tumor, ring cell carcinoma, gastrointestinal stromal tumor metastases) in $7 \%$ (16 patients), necrosis (radiation necrosis) in $2 \%$ (5 patients); hematoma in $2 \%$ (5 patients); other pathologies (primitive neuroectodermal tumor, neurocytoma, germinoma, choroid plexus papilloma, ependymoma, cavernous hemangioma, hemangioblastoma) in 3\% (7 patients) (Table II).

The histopathologic results have been confirmed by definitive histopathology obtained from open surgical resections in 36 of 242 patients $(15 \%) .18$ of 36 confirmed patients $(50 \%)$ had completely the same pathological results with definitive pathologies, while completely different results were obtained in 12 of 36 patients (33\%), and lowor intermediate-grade glial tumors were upgraded to high-grade glial tumors in 6 of 36 patients $(17 \%)$. On the other hand, 14 of 36 confirmed pathologies (39\%) were non-specific in SB, and only $5(14 \%)$ were confirmed as nonspecific in definitive surgeries, whereas 4 of 14 non-specific results were low-grade glial tumors and remaining five were high-grade glial tumors in the results of definitive surgeries. Hereby, SB was non-diagnostic in 9 of 36 confirmed patients (25\%), and false diagnostic in 3 (8\%), while open surgical resection provided a specific histopathological diagnosis. Furthermore, 24 SBs of 36 (67\%) resulted in acceptable diagnosis leading eligible further therapy (Table III). 
Table II: Histopathological diagnosis of 242 patients

$\begin{array}{lr}\text { Non-diagnostic (glial cells, gliosis) } & 46(19 \%) \\ \text { High grade glial tumor (grade } 3 \text { astrocytoma, anaplastic oligoastrocytoma, glioblastome multiforme) } & 75(31 \%) \\ \text { Low grade glial tumor (grade } 1 \text { and } 2 \text { astrocytomas, oligodendrogliomas, grade } 2 \text { oligoastrocytomas, } & 43(18 \%) \\ \text { chondroid glioma) } & 25(10 \%) \\ \text { Infectious processes (bacterial and viral inflammatory changes, tuberculoid granulomatous } & 20(8 \%) \\ \text { inflammation, encephalitis, outside substance, and abscesses) } & 16(7 \%) \\ \text { Lymphoma } & 5(2 \%) \\ \text { Metastasis (adenocarcinoma, squamous cell carcinoma, malign mesenchymal tumor, malign epithelial } & 5(2 \%) \\ \text { tumor, ring cell carcinoma, gastrointestinal stromal tumor metastases) in 7\% (16 patients) } & \\ \text { Necrosis (radiation necrosis) } & 2(0.8 \%) \\ \text { Hematoma } & 1(0.4 \%) \\ \text { Others } & 1(0.4 \%) \\ \text { Primitive neuroectodermal tumor } & 1(0.4 \%) \\ \text { Neurocytoma } & 1(0.4 \%) \\ \text { Germinoma } & 1(0.4 \%) \\ \text { Coroid plexus papilloma } & \\ \text { Epandimoma } & \\ \text { Hemangioblastoma } & \end{array}$

On the aspect of the complications associated with SB, the morbidity rate was $3.3 \%$ (8 patients), the mortality rate was $0.4 \%$ (1 patient), while $96.3 \%$ (233 patients) had not any additional deficits or problem. The morbidities have been identified as perioperative seizure in 2 cases, increasing motor deficit in 5 cases and postoperative new focal motor deficits in 2 cases. In only one patient, complication of hemorrhage was detected as non-traumatic epidural hematoma one week after SB.

\section{DISCUSSION}

Stereotactic biopsy is increasingly used up-todate and become a unique technic for unresectable lesions located in the eloquent or deep brain with diagnostic challenges. SB gives the chance of further therapy with avoiding from an extensive surgery to the patients with high mortality and morbidity. In our clinic, SBs are performed with magnetic resonance imaging (MRI) guidance, besides some clinics use computed tomography guidance ${ }^{9,10,12,17 . ~}$
Most lesions (46\%) were in the left hemisphere in our series, whereas in the Hall study (10) was mostly found in the right hemisphere (48\%). Location in the midline was relatively rare $(12 \%)$ as seen in the literature $(7 \%)^{10}$. Frontal lobe was the most common location followed respectively by parietal, thalamus, temporal, occipital, third ventricle and infratentorial cone cerebellum and one pontine).

Regarding the histopathological results, highgrade glial tumors were the most common types (31\%) followed respectively by nonspecific findings, low-grade glial tumors, infectious processes, lymphomas, metastases, necrosis, and hematoma. Our histopathological findings were matching with literature and gliomas are most commonly seen pathologies in the literature, too 8,17 . Hisatuga et al. published the three most frequent lesions as metastasis, low-grade astrocytomas, and glioblastoma multiform ${ }^{11}$. 
Table III: Comparison of stereotactic biopsy based and surgically based diagnoses of 36 patients

\begin{tabular}{|c|c|c|}
\hline No. of patients & Biopsy-based diagnosis & Surgically based diagnosis \\
\hline 1 & Non-diagnostic & Non-diagnostic \\
\hline 2 & Non-diagnostic & Non-diagnostic \\
\hline 3 & Non-diagnostic & Non-diagnostic \\
\hline 4 & Non-diagnostic & Non-diagnostic \\
\hline 5 & Non-diagnostic & Non-diagnostic \\
\hline 6 & Non-diagnostic & Pilocytic astrocytoma \\
\hline 7 & Non-diagnostic & Diffuse astrocytoma grade 2 \\
\hline 8 & Non-diagnostic & Diffuse astrocytoma grade 2 \\
\hline 9 & Non-diagnostic & Diffuse astrocytoma grade 2 \\
\hline 10 & Gemistocytic astrocytoma grade 2 & Gemistocytic astrocytoma grade 2 \\
\hline 11 & Astrocytoma grade 2 & Astrocytoma grade 2 \\
\hline 12 & Astrocytoma grade 2 & Oligoastrocytoma grade 2 \\
\hline 13 & Non-diagnostic & Anaplastic oligoastrocytoma \\
\hline 14 & Non-diagnostic & Anaplastic oligoastrocytoma \\
\hline 15 & Non-diagnostic & Glioblastoma multiforme \\
\hline 16 & Non-diagnostic & Anaplastic astrocytoma grade 3 \\
\hline 17 & Non-diagnostic & Glioblastoma multiforme \\
\hline 18 & Astrocytoma grade 2 & Anaplastic astrocytoma grade 3 \\
\hline 19 & Diffuse astrocytoma grade 2 & Glioblastoma multiforme \\
\hline 20 & Diffuse astrocytoma grade 2 & Anaplastic astrocytoma grade 3 \\
\hline 21 & Astrocytoma grade 1 & Glioblastoma multiforme \\
\hline 22 & Diffuse astrocytoma grade 2 & Glioblastoma multiforme \\
\hline 23 & Diffuse astrocytoma grade 2 & Diffuse astrocytoma grade 2 \\
\hline 24 & Anaplastic astrocytoma grade 3 & Anaplastic astrocytoma grade 3 \\
\hline 25 & High grade glial tumor & High grade glial tumor \\
\hline 26 & Anaplastic astrocytoma grade 3 & Anaplastic astrocytoma grade 3 \\
\hline 27 & Diffuse astrocytoma grade 2 & Glioblastoma multiforme \\
\hline 28 & High grade glial tumor & High grade glial tumor \\
\hline 29 & High grade glial tumor & Glioblastoma multiforme \\
\hline 30 & Toxoplasmosis & Lymphoma \\
\hline 31 & Oligodendroglioma & Radionecrosis \\
\hline 32 & Inflammatory changes & Cavernous hemangioma \\
\hline 33 & Hematoma & Cyst material \\
\hline 34 & Atypical neurocytoma grade 2 & Atypical neurocytoma grade 2 \\
\hline 35 & Ependymoma & Anaplastic ependymoma \\
\hline 36 & Primitive neuroectodermal tumor & Primitive neuroectodermal tumor \\
\hline
\end{tabular}


In overall of 242 patients in our series, the stereotactic biopsy provided a diagnostic yield of $81 \%$ in our series. This result is appropriate with other studies reported in the literature (range $80 \%$ to $99 \%)^{7-12}$. Mudginger published the rate of $17 \%$ for non-diagnostic $\mathrm{SBs}^{25}$ Similarly, in our study, 46 (19\%) of 242 patients had no tumor results in SBs.

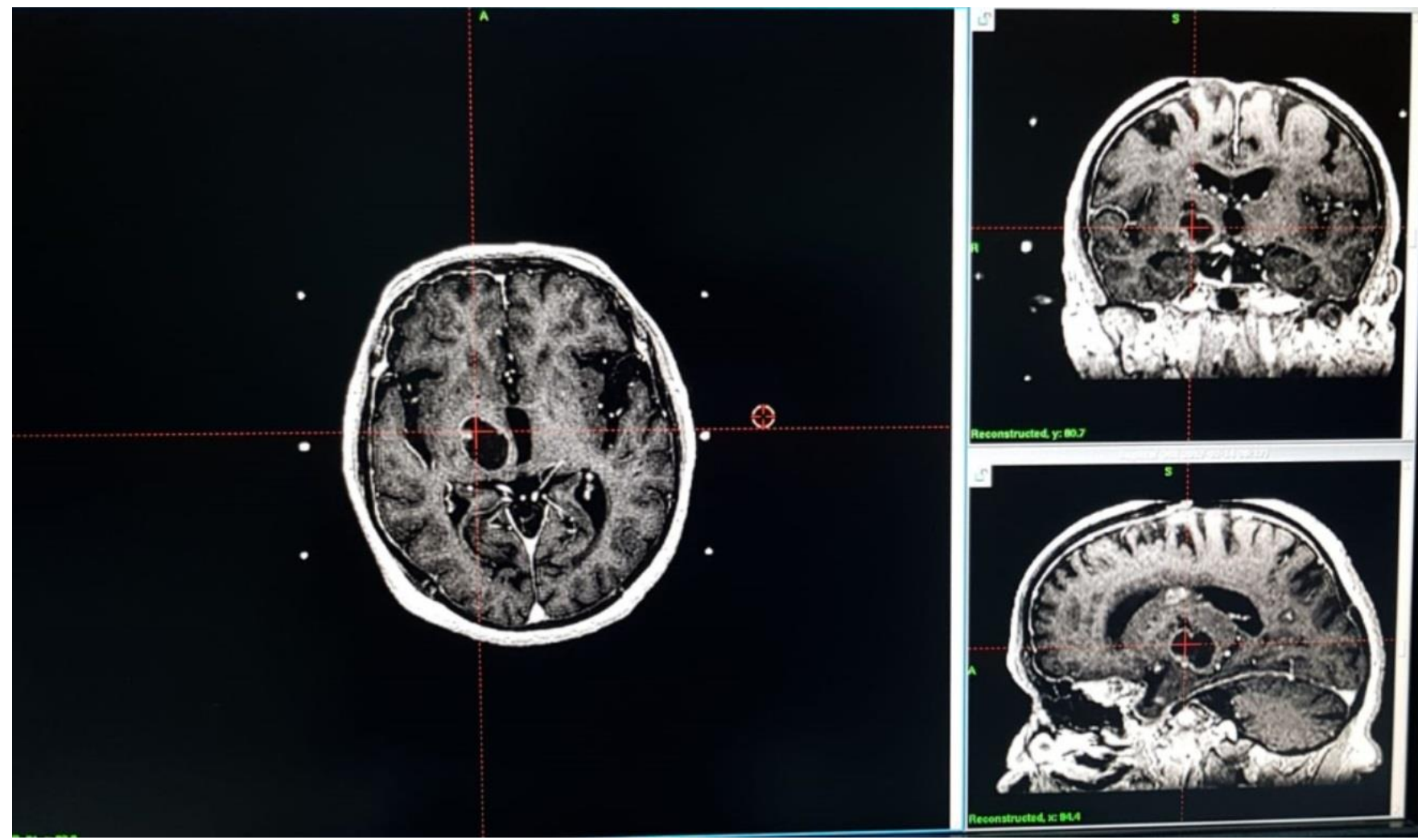

Figure 1 : Planning of right thalamic mass lesion with MR guideline

When we focused on pathological results confirmed by definitive results from open surgery, the sample size decreased to 36 patients, and the percentage of diagnostic accuracy decreased to 67\%. In Feiden et al. study, $89 \%$ of histological results in biopsy were identical with resection/autopsy tissue ${ }^{17}$. Scerrati et al. and Kim et al. had found the SB reliable as high as respectively $95 \%$ and $96.7 \%$, whereas Chandrasoma et al. and Jackson et al. had mentioned the percentage of diagnostic accuracy as low as respectively $63 \%$ and $62 \% 5,7,18,22$. Our results also pointed to the suspicion on reliability and limitations of SBs for appropriate grading and leading an appropriate treatment.

The complications belonging to the SB procedure were determined as all adverse effects acutely initiated during or after procedure within one week in our study. The main complications related with SB were mentioned as intracerebral hemorrhage, neurological worsening, and failure in diagnosis in the literature ${ }^{18,19}$. Without a doubt, SBs have a lower risk of morbidity and mortality than open surgery ${ }^{18,23}$. In our series, the rates of morbidity and mortality related SB were found respectively $3.3 \%$ and $0.4 \%$. Our rates are parallel to the literature which has the 
range of $0.7 \%-7 \%$ for morbidity, and $0.2 \%$ $2.3 \%$ for mortality $10,11,18,23-25$. In the aim of minimizing these complications, we are performing post-stereotactic biopsy computed tomography (CT) scan, while some studies advocated performing CT in evidence of bleeding in the puncture device or new deficits postoperatively rather than performing routinely ${ }^{19-21}$. To prevent progression in edema surrounding the lesion, we use steroids, diuretics or hypertonic saline if not contraindicated. Furthermore, intraoperative histopathological consultation should be used to ensure the procedure being diagnostic rather than normal tissue and rule out the material insufficiency, as suggested in Brainard et al. study $^{13}$. However, we did not perform intraoperative frozen section or cytological examination techniques during the procedure because of the shortness of the operation time. Finally, the importance of sophisticated technical skills should not be underestimated. The type of needles and forceps and development of guidance imaging studies (CT or MRI) are the types of equipment to minimize the misdiagnoses.

\section{CONCLUSION}

In our large series, the stereotactic approach to the brain mass lesions seems to be a safe and effective way to provide a histological diagnosis. The mortality $(0.4 \%)$ and morbidity $(3.3 \%)$ rates were low and the diagnostic yield (81\%) was high, whereas the diagnostic accuracy confirming with excisional biopsies was lower (67\%). Our results of outcomes belonging to SBs are seen concordant to the literature. The non-diagnostic reports could be decreased by detailed preoperative surgical planning, using suitable biopsy forceps that improving the number of specimens and performing an intraoperative histopathological examination.

This study (clinical article) took place in Department of Neurosurgery, Gazi University
Faculty of Medicine and presented as an eposter at WFNS XVI. World Congress of Neurosurgery, İstanbul, Turkey, 2017.

Declaration of Conflicting Interests: The authors declare that they have no conflict of interest.

Financial Disclosure: No financial support was received.

\section{REFERENCES}

1. Horsley V, Clarke RH. The structure and functions of the cerebellum examined by a new method. Brain. 1908; 31: 45-124.

2. Schulder M. Handbook of Stereotactic and Functional Neurosurgery, 1st edn. New Jersey Medical School, USA: CRC Press, 2003: 1-608

3. Burger PC, Nelson JS. Stereotactic brain biopsies. Pathol Lab Med. 1997; 121: 477-80.

4. Krieger MD, Chandrasoma PT, Zee CS, Apuzzo ML. Role of stereotactic biopsy in the diagnosis and management of brain tumors. Seminars in surgical oncology. John Wiley \& Sons, Inc. 1998; 14: 1-11.

5. Chandrasoma PT, Smith MM, Apuzzo ML. Stereotactic biopsy in the diagnosis of brain masses: comparison of results of biopsy and resected surgical specimen. Neurosurgery. 1989; 24: 160-5.

6. Savas A. Beyin Biyopsisi - Stereotaksik Cerrahi Tekniği. Society of Turkish Neurosurgery, Basic Neurosurgery, 2nd edn: 1999, 2010.

7. Kim JE, Kim DG, Paek SH, Jung HW. Stereotactic biopsy for intracranial lesions: reliability and its impact on the planning of treatment. Acta neurochirurgica. 2003; 145: 547-55.

8. Fritsch MJ, Leber MJ, Gossett L, Lulu BA, Hamilton AJ. Stereotactic biopsy of intracranial brain lesions. High diagnostic yield without increased complications: 65 consecutive biopsies with early postoperative CT scans. Stereotact Funct Neurosurg. 1998; 71: 36-42.

9. Greene GM, Hitchon PW, Schelper RL, Yuh W, Dyste GN. Diagnostic yield in CT-guided stereotactic biopsy of gliomas. J Neurosurg. 1989; 71: 494-7.

10. Hall WA: The safety and efficacy of stereotactic biopsy for intracranial lesions. Cancer. 1998; 82: 174955.

11. Hisatugo MK, Stavale JN, Bido JO, Ferraz FP. Image guided stereotactic approach of central nervous system lesions: accuracy, morbidity, mortality. Arq Neuropsiquiatr. 1999; 57: 615-20. 
12. Rajshekhar V, Chandy MJ. Computerized tomographyguided stereotactic surgery for brainstem masses: a risk-benefit analysis in 71 patients. J Neurosurg. 1995; 82: 976-81.

13. Brainard JA, Prayson RA, Barnett GH. Frozen section evaluation of stereotactic brain biopsies: Diagnostic yield at the stereotactic target position in 188 cases. Arch Pathol Lab Med. 1997; 121: 481-4.

14. Firlik KS, Martinez AJ, Lunsford LD. Use of cytological preparations for the intraoperative diagnosis of stereotactically obtained brain biopsies: a 19-year experience and survey of neuropathologists. J Neurosurg. 1999; 91: 454-8.

15. Reyes MG, Homsi MF, McDonald LW, Glick RP. Imprints, smears, and frozen sections of brain tumors. Neurosurgery. 1991; 29: 575-9.

16. Cappabianca P, Spaziante R, Caputi F et al. Accuracy of the analysis of multiple small fragments of glial tumors obtained by stereotactic biopsy. Acta Cytol. 1991; 35: 505-11.

17. Feiden W, Steude U, Bise K, Gundisch O. Accuracy of stereotactic brain tumor biopsy: comparison of the histologic findings in biopsy cylinders and resected tumor tissue. Neurosurg Rev. 1991; 14: 51-6.

18. Jackson RJ, Fuller GN, Abi-Said D et al. Limitations of stereotactic biopsy in the initial management of gliomas. Neuro-oncol. 2001; 3: 193-200.
19. Quick-Weller J, Lescher S, Kashefiolasl S, Weise LM, Seifert V, Marquardt G. Benefit of Stereotactic Procedures in a Series of 43 Children. J Child Neurol. 2016; 31: 907-12.

20. Eibach S, Weise L, Setzer M, Seifert V, Senft C. Intraoperative bleeding in stereotactic biopsies and its implication on postoperative management: can we predict CT findings? Stereotact Funct Neurosurg. 2014; 92: 80-5.

21. Kulkarni AV, Guha A, Lozano A, Bernstein M. Incidence of silent hemorrhage and delayed deterioration after stereotactic brain biopsy. J Neurosurg. 1998; 89:31-5.

22. Scerrati M, Rossi GF. The reliability of stereotactic biopsy. Acta Neurochir Suppl. 1984; 33:201-5.

23. Apuzzo ML, Chandrasoma PT, Cohen D, Zee CS, Zelman V. Computed imaging stereotaxy: Experience and perspective related to 500 procedures applied to brain masses. Neurosurgery. 1987; 20: 930-7.

24. Bernstein M, Parrent AG. Complications of CT-guided stereotactic biopsy of intra-axial brain lesions. J Neurosurg. 1994; 81: 165-8.

25. Mundinger F. CT stereotactic biopsy for optimizing the therapy of intracranial processes. Acta Neurochir. Suppl. 1985; 35:70-74. 